\title{
Changes in Driftwood Delivery to the Canadian Arctic Archipelago: The Hypothesis of Postglacial Oscillations of the Transpolar Drift
}

\author{
ARTHUR S. DYKE, ${ }^{1}$ JOHN ENGLAND, ${ }^{2}$ ERK REIMNITZ ${ }^{3}$ and HÉLÈNE JETTÉ ${ }^{1}$
}

(Received 4 April 1996; accepted in revised form 7 August 1996)

\begin{abstract}
Driftwood appears to be absent in the Beaufort Gyre but abundant in parts of the Transpolar Drift (TPD), which crosses the Arctic Ocean from the Chukchi Sea to the vicinity of northeastern Greenland. Nearly 300 radiocarbon dates on Holocene driftwood from the Canadian Arctic Archipelago reveal two regions with contrasting histories of driftwood incursion: the region accessible to wood brought into Baffin Bay by the West Greenland Current and the rest of the archipelago, which receives wood from the Arctic Ocean. We hypothesize that when the TPD was deflected westward along northern Greenland, wood was delivered widely to the Canadian Arctic Archipelago; when the TPD exited entirely through Fram Strait via the East Greenland Current, little or no wood was delivered to most of the archipelago, but some continued into Baffin Bay via the West Greenland Current. A split TPD delivered wood to both regions. The regional driftwood incursion histories exhibit multiple maxima and minima that can be explained by this hypothesis. The Larix to Picea ratio of wood arriving in the Canadian Arctic Archipelago has also changed through time. This may indicate varying contributions from Russian versus North American sources, which in turn may indicate variable mixing of wood en route. The inferred discharge paths of the TPD were apparently stable for intervals ranging from several millennia to centuries or perhaps only decades. The last major switch broadly correlates with the onset of Neoglaciation. Variations in the path and strength of the TPD may have important oceanographic and climatic consequences downstream in the North Atlantic Ocean.
\end{abstract}

Key words: driftwood, Transpolar Drift, Beaufort Gyre, sea ice, ocean currents

RÉSUMÉ. Il semble qu'il n'y ait pas de bois flotté dans la circulation de Beaufort mais qu'on en trouve en abondance dans certaines parties du courant d'impulsion transpolaire, qui traverse l'océan Atlantique depuis la mer des Tchouktches jusqu'au voisinage du nord-est du Groenland. Près de 300 datations au carbone 14 effectuées sur du bois flotté datant de l'holocène et provenant de l'archipel Arctique canadien mettent en évidence deux régions qui possèdent un passé divergent quant à l'incursion de bois flotté: la région que peut atteindre le bois transporté dans la baie de Baffin par le courant groenlandais oriental, et le reste de l'archipel, qui reçoit le bois en provenance de l'océan Arctique. Nous avançons l'hypothèse que, quand le courant transpolaire était défléchi vers l'ouest le long de la partie septentrionale du Groenland, il y avait un fort apport de bois dans l'archipel Arctique canadien; quand le courant transpolaire passait en sa totalité par le détroit de Fram pour rejoindre le courant groenlandais oriental, peu de bois, sinon aucun, atteignait la plupart de l'archipel, un peu étant cependant acheminé dans la baie de Baffin via le courant groenlandais occidental. Un courant transpolaire divisé amenait du bois aux deux régions. L'historique des incursions régionales de bois flotté révèle l'existence de nombreux maxima et minima que peut expliquer cette hypothèse. Le rapport du bois provenant de Larix à celui provenant de Picea transporté dans l'archipel Arctique canadien a aussi évolué au cours du temps. Cela peut indiquer une variation dans la contribution provenant de Russie par rapport à celle provenant d'Amérique du Nord, ce qui, à son tour, peut révéler un mélange variable de bois durant le parcours. Les trajets inférés de la décharge du courant transpolaire ont été apparemment stables durant des périodes allant de plusieurs millénaires à des siècles, voire des décennies. Le dernier grand changement est, dans l'ensemble, corrélé à l'arrivée de la néoglaciation. Les variations dans le trajet et la puissance du courant transpolaire pourraient avoir d'importantes conséquences océanographiques et climatiques en aval dans l'océan Atlantique Nord.

Mots clés: bois flotté, courant transpolaire, circulation de Beaufort, glace de mer, courants océaniques

Traduit pour la revue Arctic par Nésida Loyer.

\footnotetext{
${ }^{1}$ Terrain Sciences Division, Geological Survey of Canada, 601 Booth Street, Ottawa, Ontario K1A 0E8, Canada; ad@gsc.nrcan.gc.ca

${ }^{2}$ Department of Earth and Atmospheric Sciences, University of Alberta, Edmonton, Alberta T6G 2E3, Canada

${ }^{3}$ Pacific Marine Geology, United States Geological Survey, 345 Middlefield Road., MS 999, Menlo Park, California 94025, U.S.A. Climate Systems History and Dynamics Project Contribution 6-4; Geological Survey of Canada Contribution 1996101

(C) The Arctic Institute of North America
} 


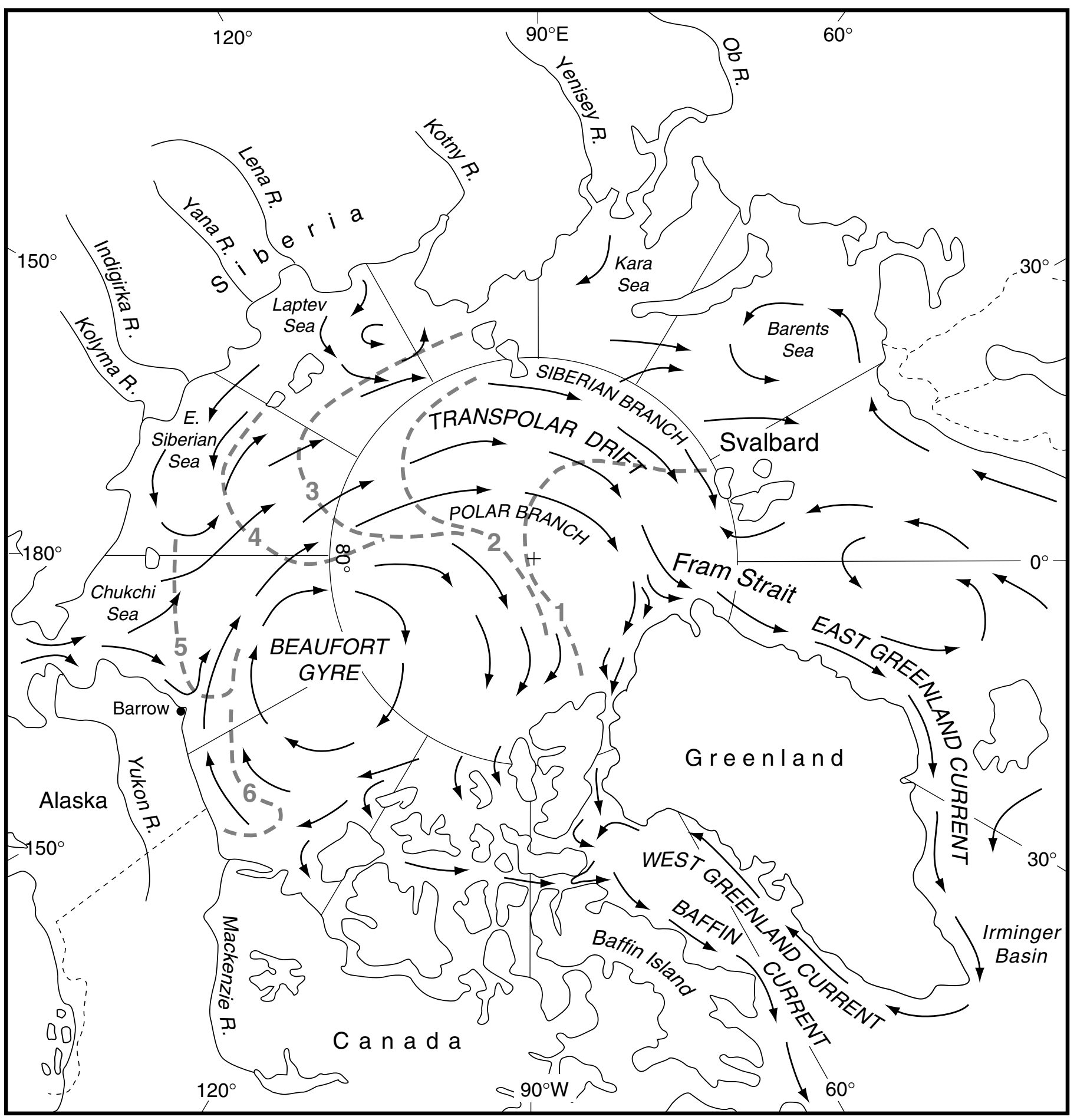

FIG. 1. Generalized Arctic Ocean currents, modified from Ostenso (1966), Stewart and England (1983), Reimnitz et al. (1994). Isochrones labelled 1-6 give the average number of years for a floating object to enter the Atlantic (Rigor, 1992).

\section{INTRODUCTION}

For decades, driftwood derived mainly from boreal forests has been collected from raised beaches and archaeological sites of Arctic Canada, Alaska, Greenland, and Svalbard. For the Canadian Arctic Archipelago, the radiocarbon database now comprises 299 dates on nonarchaeological driftwood. These dates reveal two contrasting regional patterns in the chronology of driftwood penetration to Arctic Canada. The patterns defy a simple climatological interpretation and suggest instead changes in routes of wood delivery.

We hypothesize changes in the trajectory of the Transpolar Drift (TPD), the major sea-ice conveyor belt of the Arctic Ocean, as the causal mechanism. The Beaufort Gyre, the other major circulation feature of the Arctic Ocean (Fig. 1), is driven by anticyclonic winds (e.g., Barry, 1989). The TPD 
is commonly described as comprising two branches: the lefthand part, originating in the Laptev Sea off Siberia, forms the Siberian Branch; the right-hand part, originating from the fringe of the Beaufort Gyre and from an inflowing Pacific current, forms the Polar Branch (Fig. 1). Transit times from ice and wood source areas to Fram Strait are from three to six years (Rigor, 1992). The Arctic Ocean comprises only $1 \%$ of the world's ocean water, but it receives $10 \%$ of global freshwater input, about $3000 \mathrm{~km}^{3}$ annually. Most of this freshwater is exported to the Atlantic as sea ice, about $70 \%$ via the East Greenland Current and 30\% via the Canadian Arctic Archipelago and the Baffin Current (Arctic System Science, 1990).

In the analysis below, we exclude dates on driftwood charcoal from archaeological sites in order to avoid the probable bias of overrepresenting episodes of human occupation. While there is generally a positive correlation between driftwood availability and driftwood use amongst prehistoric Inuit groups in the Arctic (see e.g., Arnold, 1994), the extent to which its use may have significantly depleted driftwood occurrences within specific survey areas is unknown. However, because prehistoric Inuit populations were probably extremely small and occupations within any one region were generally intermittent, there is no reason to believe that removal of wood by prehistoric inhabitants might have more seriously affected any one large region of the archipelago (as used here) than another. With respect to his Cape Storm study site, Blake (1975:35) remarked in this regard: "the fact that so many driftwood logs are present on the beaches...suggests to the writer that the former inhabitants utilized little of the abundant wood available."

In general, wood in the Canadian Arctic Archipelago is orders of magnitude less abundant than in the Svalbard Archipelago, (cf. Blake, 1972; Häggblom, 1982). For example, on Hopen Island in Svalbard, abundances can be measured in pieces of wood per $\mathrm{m}^{2}$ ! Comments below, however, refer to Canadian samples unless otherwise indicated. Detailed information on samples used here is available on request from the Radiocarbon Laboratory, Geological Survey of Canada. Wood is an excellent material for dating; the two-sigma standard errors on Geological Survey of Canada (GSC) wood dates, which comprise $71 \%$ of our database, are typically $40-50$ years.

Blake $(1972,1975)$ was the first to recognize that postglacial driftwood penetration to the Canadian Arctic varied markedly through time. He pointed out the potential of the driftwood record for reconstructing changes in ocean currents or in climate. He documented an interval of abundant wood arrival at Cape Storm, Jones Sound (Fig. 2), in the middle Holocene and inferred this to be a period of less severe summer sea ice. Although Blake did not explicitly consider the processes of wood delivery, transport, and stranding, this record of driftwood incursion has become the best-known and most often cited evidence of a middle Holocene "hypsithermal" in the Canadian High Arctic (e.g., Williams and Bradley, 1985; Koerner, 1989). Stewart and England (1983) examined the driftwood record of Clements Markham
Inlet on the Arctic Ocean coast of Ellesmere Island, along with a larger regional data set than was available to Blake (1972) for the Canadian Arctic Islands and northwest Greenland, which included wood from archaeological sites. However, they drew inferences similar to Blake's regarding regional summer sea-ice conditions and paleoclimate.

Dyke and Morris (1990) presented additional driftwood dates for the central Canadian Arctic Archipelago (Fig. 2). Peak driftwood incursion there occurred during the Neoglacial period (last 2500 years). In the same region at that time, increased summer sea-ice severity is inferred to have caused a sharp reduction in the summer range of the bowhead whale (Dyke and Morris, 1990; Dyke et al., 1996b). In contrast, the Neoglacial was a period of minimal driftwood incursion in the adjacent region discussed by Blake (1972). Hence, Dyke and Morris (1990) concluded that the chronology of driftwood abundance is not uniform across the Arctic Islands and, therefore, is not a simple indicator of either regional paleoclimate or past sea-ice conditions in the stranding areas.

Clearly, a middle Holocene peak in driftwood incursion in one region cannot be taken as prima facie evidence of a "hypsithermal" if the peak in wood incursion in an adjacent region occurred during the Neoglacial. Thus, at present we are faced with well-documented, but contrasting, regional patterns of driftwood incursion that seemingly cannot be consistently interpreted in terms of regional paleoclimate or of sea-ice conditions.

\section{DISTRIBUTION AND TRANSPORT OF DRIFTING WOOD}

Driftwood from the boreal forests reaches the Arctic Ocean from North America and Eurasia (e.g., Eurola, 1971). Most wood is delivered to the ocean as a consequence of bank erosion by major rivers that traverse the forests: the Mackenzie, Yukon, Ob, Yenisey, Lena, Kotny, Yana, Indigirka, and Kolyma (Fig. 1).

Published observations of the distribution of drifting logs in the Arctic Ocean are rare (Pfirman et al., 1989). However, Mackenzie River driftwood is abundant along the coastline both east and west of its delta, as has long been known (Kindle, 1921; Eurola, 1971). Driftwood grown in the Yukon-Kuskokwim drainage basins of western Alaska has been traced along Alaskan beaches north as far as Barrow, located at the fringe of the Beaufort Gyre; east of Barrow, the driftwood seems to be mainly of Mackenzie origin (Giddings, 1952). However, our own field observations suggest that the supply of both Mackenzie and Yukon-Kuskokwim driftwood to the Beaufort Gyre is rather meagre and that most of the former may end up stored on the north coast of Alaska.

The United States Geological Survey has unpublished observations on modern driftwood in the coastal fringe of the Beaufort Gyre (Fig. 1) from over 30 field operations spanning the last 25 years. More than 20 summer months were spent aboard small vessels in geological studies of the inner Beaufort Shelf. These studies included mapping of driftwood 
accumulations on the coastal plain. During this time no logs were ever seen adrift. However, an abundance of logs that accumulated in 1970 marks the extent of a storm-surge inundation that reached as far as $5 \mathrm{~km}$ inland (Reimnitz and Maurer, 1979).

Despite the scarcity of drifting wood, this accumulation seems to be mostly of Mackenzie origin. Much of it is too large to have originated from Alaska North Slope rivers (Reimnitz and Maurer, 1979). Seven out of 35 wood samples recently collected from the North Slope were identified through dendrochronological methods as originating in the Mackenzie River drainage basin, and none evidently came from the Yukon-Kuskokwim rivers (O. Eggertsson, written comm. to Reimnitz, 1995). The scarcity or lack of logs afloat, however, indicates a meagre wood supply for the Beaufort Gyre from the Mackenzie source today.

The thousands of logs stored in the 1970 storm-surge line, 2-3 m above mean sea level (Reimnitz and Maurer, 1979), must have been scavenged from the modern Beaufort and possibly Chukchi coasts. Thus, storm surges in the Beaufort Sea concentrate wood delivered during inter-surge periods into strandlines that are above the reach of normal tides. There the wood is preserved for a century or more in a predominantly dry and frozen setting. Many of the logs deposited in 1970 are so sound that they burn well and would float again in a similarly high surge. However, most refloated wood presumably would end up in a new surge line. Such high surges are estimated to occur only once a century or less often. In speculating about the recycling and dispersion of old driftwood, one must consider the fact that storm surges on the north coast of Alaska are driven by westerly winds. Any wood refloated by a storm surge, therefore, would be herded back toward the Mackenzie source, contrary to the general rotation of the Beaufort Gyre (Fig. 1).

Since 1988, the U.S. Geological Survey has participated in nine expeditions using American, German, and Russian icebreakers in efforts focused on studying the transport of foreign substances by sea ice in all major ice streams of the Arctic Ocean. Some expeditions had extensive helicopter support. Wood is easily spotted from the elevation of the ship's bridge and from the air, especially since the heatabsorbing properties of logs keep them bare of snow, and many logs protrude above the general ice surface. Very extensive areas of dirty ice with logs have been observed in the TPD originating off Siberia. But no logs have been sighted so far in the pack ice of the Beaufort Gyre.

The lack of driftwood observed by us in the Beaufort Gyre does not mean that this circulation system and the Polar Branch of the TPD into which it feeds carry no wood. But the Polar Branch carries much less wood than the Siberian Branch of the TPD. In fact, natives from Barrow report occasional driftwood, usually in August, marking the convergence between the north-flowing current in the Chukchi Sea, originating in Bering Strait, and the Beaufort Gyre (Richard Glenn, oral comm. to Reimnitz, 1995). Furthermore, on the shores of East Greenland and southeastern Baffin Island, wood from both the Yukon and Mackenzie Rivers has been identified by cross-dating of tree-ring series (Eggertsson, 1994b; Eggertsson and Laeyendecker, 1995). Thus the Polar Branch of the TPD today delivers some wood to the East Greenland Current and systems downdrift.

A paucity of wood in the Beaufort Gyre, other than in its coastal fringe, can be explained by (a) coast-parallel currents that hamper offshore dispersion of wood and (b) the narrow lead between the Beaufort coast and the perennial pack ice that limits offshore dispersion of drifting wood by wind.

The concentration of wood in the TPD may reflect a large yield of wood from the Siberian rivers. But it may also result in part from the configuration of ocean currents. On average, currents move wood westward along the north coast of Alaska and eastern Siberia and eastward along the central Siberian coast. These coastal currents converge in the East Siberian Sea and combine with the inflowing Pacific current, which brings Yukon River wood, to form the TPD (Fig. 1). Even wood of North American origin reaches the Canadian High Arctic islands only via this route, presumably travelling mainly in the Polar Branch of the TPD. Hence, the TPD delivers driftwood to Svalbard, Greenland, and Arctic Canada. In additon, Mackenzie River driftwood directly reaches a small part of the southwestern Canadian Arctic Archipelago by an eastward-flowing coastal current.

\section{CONTROLS ON DRIFTWOOD ABUNDANCE IN ARCTIC CANADA}

The radiocarbon samples, and to some extent the driftwood, are unevenly distributed geographically as well as through time. Most wood has been found in and on the raised beaches of the High Arctic islands. Many of these raised beaches are unvegetated because of high alkalinity, low nutrient availability, aridity, or cold climate. Even small wood fragments and logs with little surface exposure are conspicuous there. In contrast, few driftwood samples have been collected from the well-vegetated, acidic, raised beaches of eastern Baffin Island and the arctic mainland. Wood there may have rotted. Logs in the Low Arctic tundra mat of northern Alaska, for example, seem to decompose in just a century or two (Reimnitz and Maurer, 1979).

Within the High Arctic, the uneven distribution of samples partly reflects an uneven searching of the emerged terrain. But most of the archipelago has now received more than cursory attention, and wood is known to be relatively abundant in some areas yet exceedingly rare in others. Wood abundance changes from channel to channel and along the shores of a channel. For example, wood is much more abundant along Barrow Strait and Wellington Channel than along Prince Regent Inlet (Fig. 2), but it is not yet possible to quantify the pattern of abundance meaningfully. What has determined this variable intraregional distribution?

Differences in rates of wood incursion and in stranding potential are the most probable causes. Locally, shoreline orientation may affect stranding potential. For example, Blake (1972) noted that driftwood along the north shore of 


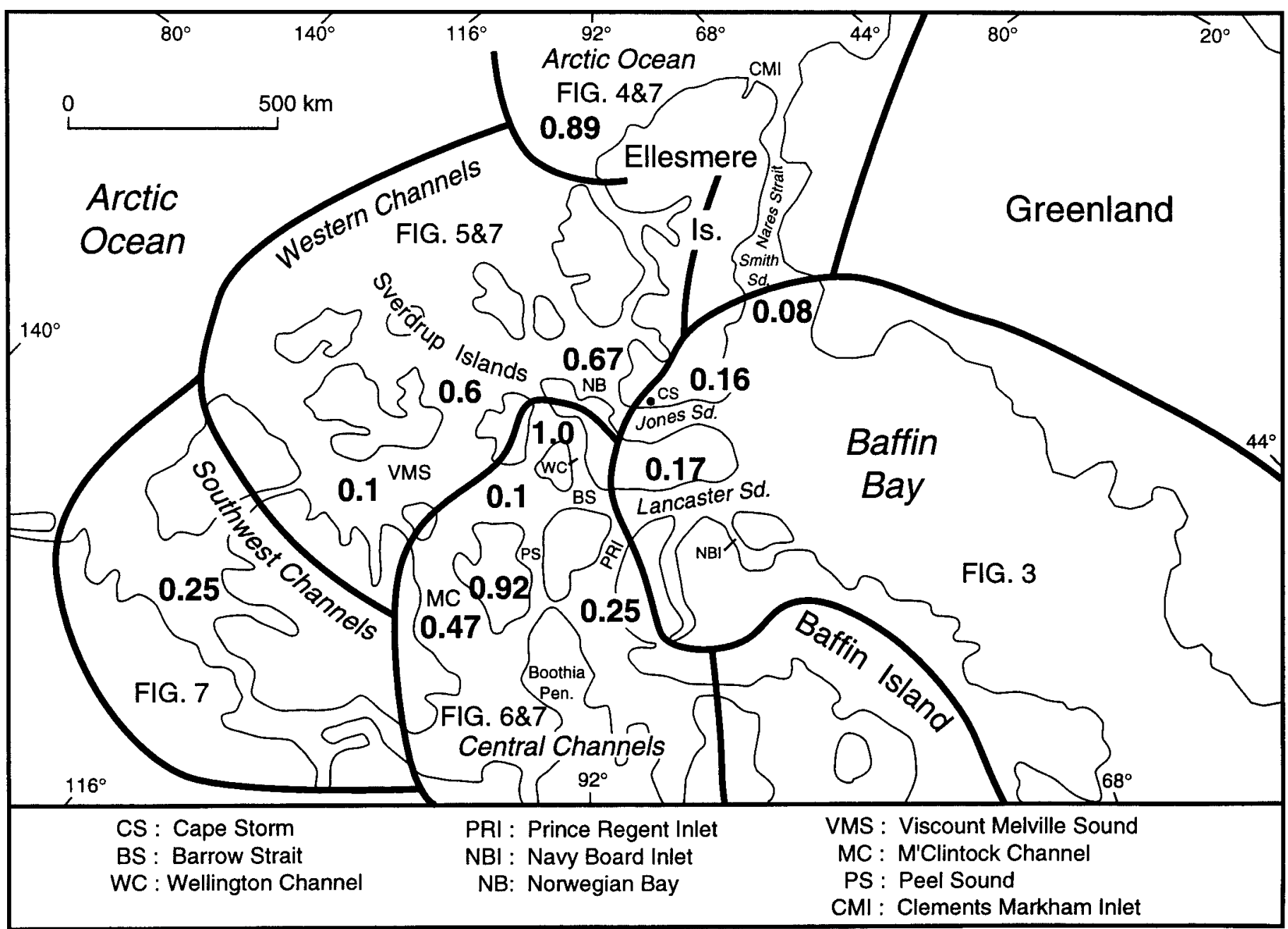

FIG. 2. The ratio of Larix to Picea in radiocarbon-dated driftwood samples from the Canadian Arctic Archipelago. Sample areas for frequency distributions of radiocarbon dates (Figs. $3-7$ ) are outlined.

Jones Sound (Fig. 2) is most abundant on beaches that face into the west-flowing current there. This orientation effect probably explains many small-scale changes in wood abundance, but cannot explain a changing abundance of wood through time. Changes in landfast ice extent may be more important. Formation of perennial landfast ice brings local stranding potential to zero. The percentage of coastline occupied by landfast ice thus largely governs regional stranding potential. However, landfast ice does not hamper regional wood incursion unless it extends across the interisland channels; wood simply bypasses landfast ice to possibly strand elsewhere. Increasing extent of summer open water within the archipelago would arguably increase stranding potential but would not affect regional rates of wood incursion. Length of the open water season and local transit times (distances) to shore are both too brief to reduce stranding potential seriously by waterlogging and sinking of wood (see below).

This view reduces the problem to distinguishing those changes in local driftwood chronologies that reflect changing landfast ice extent, a function of local summer climate, from changes that reflect a changing wood incursion rate, a function of conditions in more remote areas (wood supply and delivery route). Local driftwood chronologies that reflect the variable abundance of wood in raised beach sequences (e.g., Blake, 1972, 1975 for Cape Storm) presumably reflect changes in incursion rate rather than in stranding potential for two reasons: (1) beaches cannot form behind perennial landfast ice, and (2) a coastline exposed to beach-forming processes probably is also available for stranding of wood. On the other hand, a scarcity of driftwood in an area of poorly formed raised beaches may indicate persistent landfast ice, particularly if beaches of the same age in areas downdrift are woodbearing.

Correlations between driftwood abundance and summer open water extent in the interisland channels, which would support a direct climatological interpretation of the driftwood record, have never been demonstrated. Indeed, there is no reason in principle to suspect a positive correlation. Though local open water might encourage stranding of wood, it is not essential, in that wood can be shoved ashore by (or on) loose sea ice. We do not know which of these conditions provides the greater stranding potential, because there is no body of observations on the processes of wood release and stranding. 
However, extensive open water is inimical to long-distance transport of wood. For example, Häggblom (1982) pointed out that buoyancy periods, which are less than 17 months for spruce and only 10 months for larch, are too short, in the absence of sea ice, to achieve transpolar or circumpolar transport. Transarctic transport takes 3-6 years with transport rates of about $600 \mathrm{~km}$ per year in the TPD (Fig. 1). Because of the short summers, however, wood brought to the Arctic Ocean will have to remain buoyant for a few months at most before it is frozen into sea ice. Once frozen in, most wood will remain in or on the ice, because the multiyear ice of the Arctic Ocean is much thicker than can melt in a summer (Barry, 1989).

Sea ice, then, is the essential transporting agent for fartravelled driftwood. For this reason, Häggblom (1982) assumed a negative correlation between wood abundance and the extent of open water north of Svalbard in his interpretation of the record of driftwood incursion of Hopen Island. Wood-barren zones were interpreted as intervals with long summers, when the open water to the north was too extensive to be crossed by free-floating wood. However, ice in the Arctic Ocean remains mobile and transports wood throughout the year; even under conditions of extensive summer ice clearance, wood should arrive in a region during the nonsummer months and be available for stranding during ice breakup and recession.

Even if Häggblom's hypothesis partly explains the variable wood delivery to Svalbard, it seems unlikely that there were periods during the Holocene when there was too little ice in the Arctic Ocean to deliver wood to the Canadian Arctic Archipelago. The pack ice never pulls far back from the Arctic Ocean coast of the archipelago, which is a region of ice convergence, even in the warmest summers (Barry, 1989), and we are not aware of any evidence that conditions off this coast were significantly different during the Holocene. We therefore seek explanations of the driftwood incursion patterns in terms of changes in provenance or in transport routes.

Velocity of transport may also have changed. But the rate of transport of wood by the sea ice probably would not affect the incursion rate in stranding regions. For example, a slower rate of ice movement would be compensated by a higher concentration of wood in transit, as long as the rate of wood supply to the ocean and its entrainment in sea ice remained unchanged. Whether wood supply rates have changed during the Holocene is less easy to assess, but we will return to this later.

\section{HYPOTHESIS}

Our hypothesis is based on the assumption that the TPD has been the only significant wood-dispersing current that could have delivered driftwood to the Canadian Arctic Archipelago during postglacial time. We hypothesize that the different patterns of driftwood penetration to the Canadian Arctic Archipelago and the mix of species involved (both discussed below) are due to changes in the trajectory of the TPD. Note that this current today approaches North America near the apex of northeastern Greenland (Fig. 1). A lateral shift of the distal part of the current by about its own width, or less, could have the effect that: 1) the entire current would exit the Arctic Ocean east of Greenland, either feeding entirely into the East Greenland Current via Fram Strait or splitting around Svalbard;2) the entire current would be deflected westward along the coast of North Greenland; or 3) the current would be more or less evenly split between these two routes.

If the entire TPD, with its sea ice and wood load, exited Fram Strait via the East Greenland Current, some of the ice and wood should eventually be carried northward into Baffin Bay by the West Greenland Current. Some of this would strand on the shores accessible to currents flowing into the southeastern part of the Canadian Arctic Archipelago from Baffin Bay, but little or no wood would be delivered to other parts (i.e., most) of the archipelago. If the distal TPD were deflected entirely westward, wood should become available for widespread stranding throughout the Canadian Arctic Archipelago, but none would be delivered by the West Greenland Current unless contributed by sources other than the TPD. A TPD splitting at northeastern Greenland would deliver wood by both routes.

Regarding the mix of wood from different sources reaching Arctic Canada, both the route of the TPD and its style of flow may be important. A TPD with perfectly laminar flow will carry North American wood along its Polar Branch and Russian wood along its centre and left (Siberian Branch). Thus, a larger westward shift of the distal TPD would be required to deliver Russian wood to the Canadian Arctic Archipelago than to deliver North American wood. A TPD with internal eddies should mix wood in transit. We have no information on how much mixing occurs today or under what conditions it occurs. It seems probable, however, that the recently discovered, brief, annual reversals of the Beaufort Gyre (McLaren et al., 1987) could induce such mixing. These reversals occur in summer when the normal anticyclonic atmospheric circulation over the Canada Basin is replaced by transient cyclones.

Below we argue that the hypothesis of a shifting TPD can explain the contrasting driftwood chronologies of Arctic Canada. The hypothesis is based on the observed distribution and movement of wood and not on the driftwood chronologies themselves. We examine the driftwood types, changes of wood types through time, and then the incursion histories for the two relevant parts of the Canadian Arctic Archipelago-the part that could have received wood from Baffin Bay and the part that could not. Radiocarbon dates are plotted on histograms with 250year class intervals. We have chosen a class interval larger than the two-sigma standard errors (typically about 50 years) to insure that most dates plotted in adjacent intervals are significantly different. Our purpose is to show the details that can be explained by the hypothesis and thus to suggest a history of shifting of the TPD. 


\section{HOLOCENE DRIFTWOOD}

\section{Wood Types, Sizes, and Provenances}

The dated driftwood from Arctic Canada is almost entirely spruce (Picea spp., 168 samples) and larch (Larix spp., 79 samples) with rare occurrences of pine (both red pine type, Pinus sylvestris or P. resinosa, and white pine type, P. monticola or P. strobus; total of 10 samples). More rare are willow (Salix spp. larger than $S$. arctica; 4 samples), hemlock (Tsuga spp., 2 samples), and aspen or poplar (Populus spp., one sample). An additional 25 dated samples have not been identified or are identified only as "spruce or larch." Identifications are by the Geological Survey of Canada's Paleoecology Laboratory. Most are published in the GSC Radiocarbon Date List series (e.g., McNeely and Jorgensen, 1993), but additional samples were identified for this study, and 16 previously published samples were reexamined to more confidently separate spruce and larch.

Our samples are identified on the basis of cell morphology viewed in thin section with two angles of section each (Panshin and de Zeeuw, 1980). Apart from the pines, identification below the generic level is not yet possible by this method (e.g., Eggertsson, 1993). Even the distinction between spruce and larch is unclear for many specimens, and seven of our samples are identified as Picea spp. or Larix spp. Hence, the present level of anatomical identification precludes distinction of wood from North American versus Eurasian sources (e.g., Larix laricina versus $L$. sibirica; Picea glauca versus $P$. obovata). However, the identifications confirm that sources are almost exclusively in boreal forests, and they allow us to evaluate the mix of wood types.

Exceptions to boreal forest sources are the two samples identified as hemlock. Presumably, these made their way into the TPD via the Bering Strait and the Alaska Current from the coastal forest of southeastern Alaska or British Columbia.

Small diameters and ring widths of driftwood from raised beaches in Arctic Canada are consistent with sources in the northern parts of boreal forests. Most wood occurs as fragments, less than $20 \mathrm{~cm}$ in diameter and less than $1 \mathrm{~m} \mathrm{long}$, rather than as logs. Exceptional pieces are several metres long and as much as $30 \mathrm{~cm}$ in diameter. Growth rings are clear and mostly less than $2 \mathrm{~mm}$, typically about $1 \mathrm{~mm}$ wide. Except for a single occurrence of birch bark (without wood), all samples lacked bark. Hence, the wood was derived mainly from small-diameter trees that suffered much abrasion and fragmentation in transit, probably by sea ice. Most of the wood, especially older and larger embedded pieces, is extensively cracked along the grain and delaminated along growth rings. It generally falls apart on removal from the raised beaches. Fortunately, however, the wood exhibits little decomposition and is thus suitable for radiocarbon dating. None of this wood shows any sign of human modification.

The boreal forests on both continents contain spruce, larch, and pine, but in very different proportions. The northern boreal forest of North America is generally dominated by spruce (Ritchie, 1989). Spruce is by far the dominant, typically the only, conifer along the banks of the Mackenzie River and its tributaries. Larch in the region "occurs very locally as a codominant of Picea glauca on calcareous uplands and as a codominant of Picea mariana in minerotrophic bogs and fens... . It becomes locally dominant and co-dominant with Picea glauca at treeline in the Richardson Mountains only on calcareous substrata" (Ritchie, 1984:58). In contrast, the conifers of eastern Siberia are heavily dominated by larch, followed by pine, whereas spruce is absent. Spruce increases in abundance westward in Russia but still comprises only $1 \%$ of the forest south of the Laptev Sea (the head of the Siberian Branch of the TPD), where larch comprises $88 \%$ and pine $11 \%$. Spruce increases to dominance in western Siberia but could only enter the fringe of the Siberian Branch of the TPD or the Barents Sea (see Table 2 and Fig. 7 in Eggertsson, 1994a; also Hustich, 1966; Eggertsson and Laeyendecker, 1995). Ritchie (1984:41) contrasts the forest composition on either side of the Bering Strait as follows: "the dominant coniferous trees of all upland and lowland boreal woodlands or forests are quite different in the two parts of Beringia: Larix dahurica and Pinus pumila in Siberia and Picea glauca and P. mariana (chiefly) in Alaska-Yukon."

Given this stark contrast in forest composition, the ratio of Larix to Picea in Canadian Arctic driftwood probably reflects contributions from the two source areas. This view is supported by data on modern driftwood composition. For example, Kindle (1921) described a huge mass of drifting timber on the Mackenzie River as consisting mainly of spruce and poplar. More recently, a collection of 130 driftwood samples along the lower Mackenzie River yielded 80\% spruce and $20 \%$ poplar, along with trace amounts of birch (Betula sp.) and alder (Alnus sp.). Larch was found in only one sample out of 290 from the Mackenzie Delta region and is only a minor constituent of Yukon River driftwood (Eggertsson, 1994b). Pine was not found in Mackenzie River driftwood despite its presence in the drainage basin, so the nine samples of pine from the Arctic Archipelago are presumably from Russia. Eurola (1971, quoting Zukov, 1940) reports pine, larch, and spruce among the driftwood at the mouths of central Siberian rivers.

The ratio of Larix to Picea in identified and dated Holocene driftwood samples from Arctic Canada shows a strong regional pattern (Fig. 2). The ratio is low $(0.1-0.25)$ on both the western and eastern flanks of the archipelago, but high ( $0.47-$ 1.0) in a long axial swath extending from northern Ellesmere Island southward to Boothia Peninsula. This pattern is tentative in detail because some sample sizes used to calculate the individual ratios are small (see Figs. 3-7 for within-channel sample sizes). However, the larch-rich zone is well sampled, as is the spruce-rich zone at the head of Baffin Bay. Furthermore, eight of the ten pine samples are from the region of abundant larch. This pattern suggests that wood from eastern Russian rivers has been more common in the axial part of the archipelago than elsewhere, whereas wood from the Mackenzie and Yukon Rivers has been more common in both the Beaufort Sea and Baffin Bay regions.

Stratification of data in the various regions considered below suggests that the generic mix may have changed 

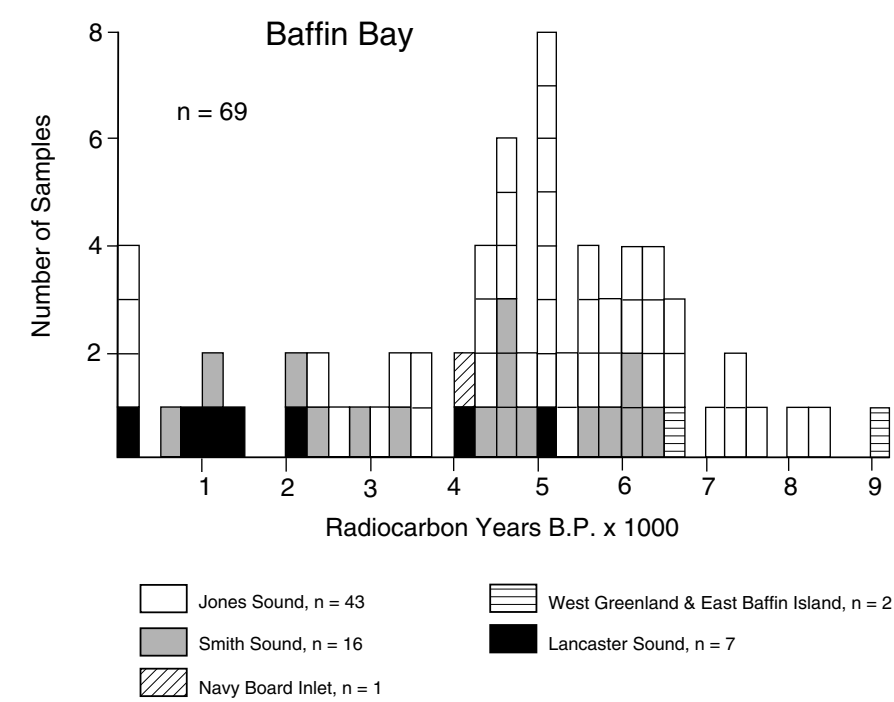

FIG. 3. Frequency distribution of radiocarbon dates on driftwood from the Baffin Bay region.

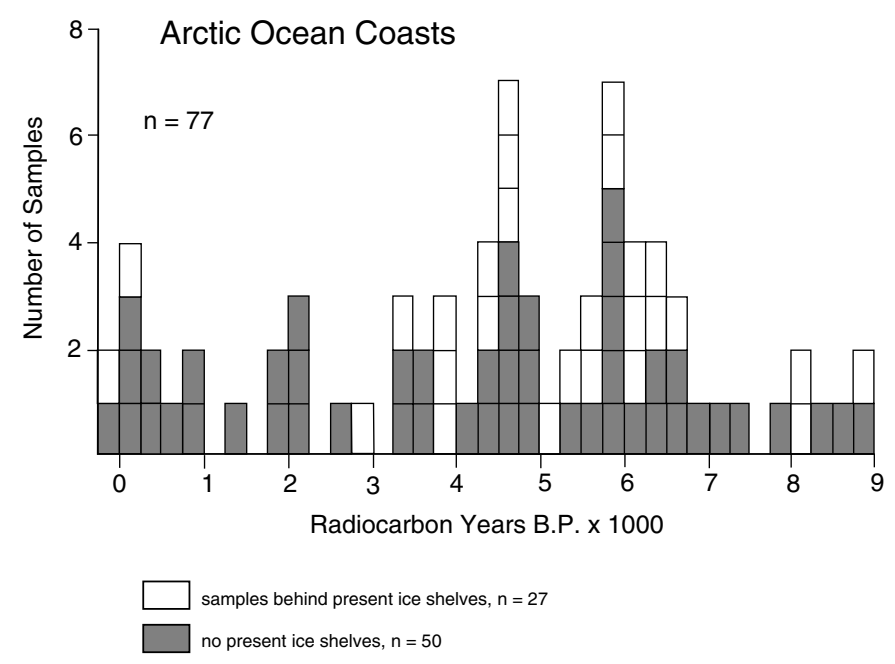

FIG. 4. Frequency distribution of radiocarbon dates on driftwood from the Arctic Ocean coast of Ellesmere Island. Samples that date "modern" are plotted to the left of 0 years B.P.

through time (Table 1). Relative abundances of larch increase in the two middle Holocene intervals and decrease in the Neoglacial (last $3 \mathrm{ka}$ ) in both the Arctic Ocean and Central Channels regions (see Fig. 2 for definition of regions and the discussion below for selection of time intervals). Hence, the ridge of high ratios of Figure 2 is not a feature of the Neoglacial driftwood influx, when this ratio was low everywhere, but strongly characterizes the middle Holocene influx. These ratios suggest that either wood provenance has changed through time, with a greater Russian contribution during the middle Holocene, or the forest mix in the source areas has changed. The western Canadian boreal forest appears to have achieved its modern composition about $6 \mathrm{ka}$ B.P. and maintained it thereafter (Ritchie, 1989). Thus, we infer shifting sources of driftwood reaching Arctic Canada during the early, middle, and late Holocene.

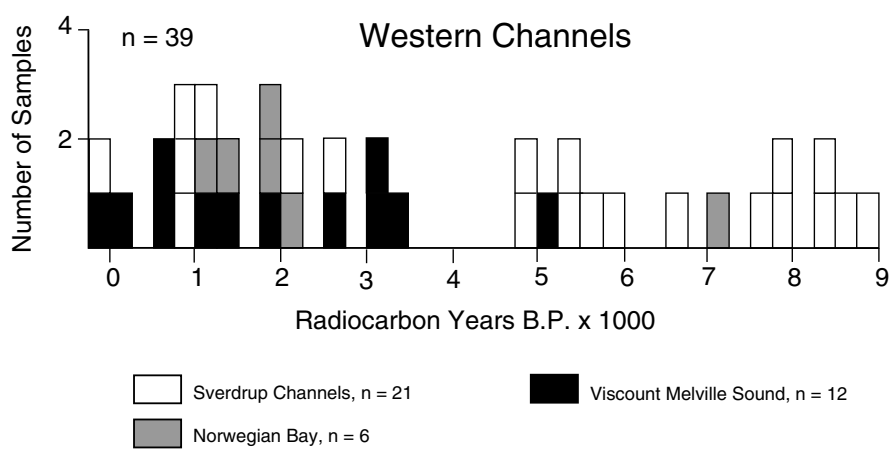

FIG. 5. Frequency distribution of radiocarbon dates on driftwood from the Western Channels region.

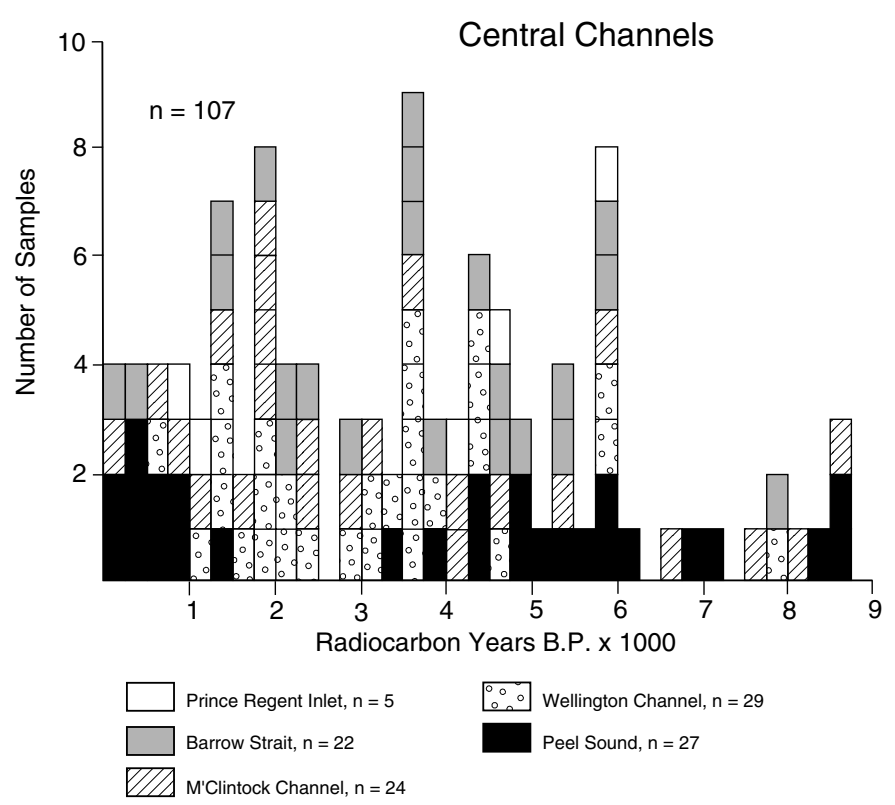

FIG. 6. Frequency distribution of radiocarbon dates on driftwood from the Central Channels region.

\section{Incursion Histories}

The probabilities that the apparent changes in driftwood abundance discussed below are due to chance alone are listed in Table 2. Note that the probabilities that the stronger modes are due to chance generally are less than 5\% and commonly are less than $1 \%$.

Region Accessible from Baffin Bay: The east coast of Baffin Island and the coast of Ellesmere Island south of Smith Sound are accessible to wood brought into Baffin Bay by the West Greenland Current. Arctic Ocean water also flows into the head of Baffin Bay via Nares Strait. In addition, Jones and Lancaster Sounds carry inflowing currents from Baffin Bay along their north shores. These currents turn and exit along the south shores where they join water flowing southeastward through the Arctic Archipelago directly from the Arctic Ocean (Fig. 1). Hence, Smith, Jones, and Lancaster Sounds and eastern Baffin Island can receive wood either from Baffin Bay or from the Arctic Ocean.

The frequency distribution of driftwood ages for the Baffin Bay region (Fig. 3) is dominated by the data from Cape Storm 


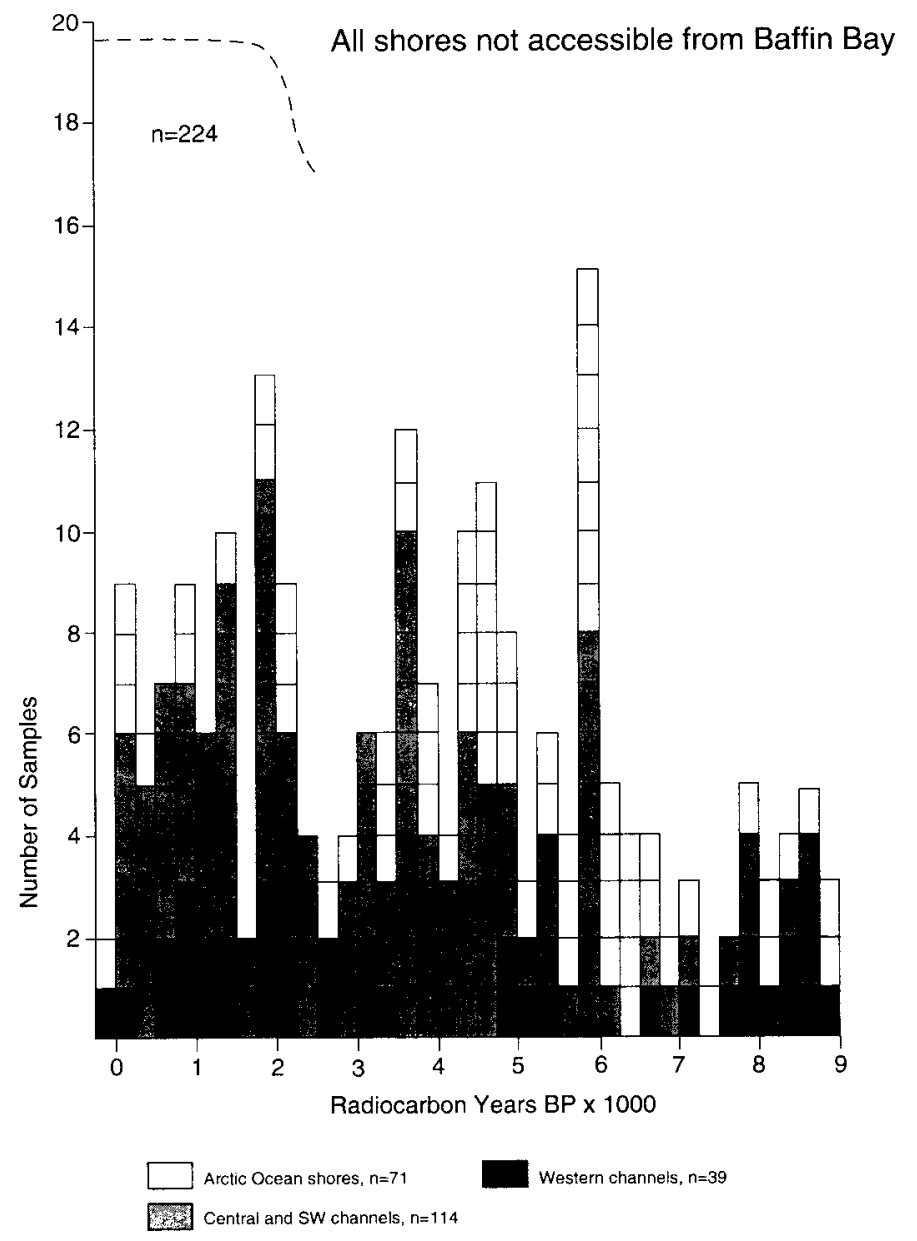

FIG. 7. Aggregate frequency distribution of radiocarbon dates on driftwood from the region not accessible from Baffin Bay. The dashed line represents the postulated frequency with sampling and dating biases removed.

(Jones Sound) and thus resembles the pattern described by Blake (1972). The oldest dated driftwood from the region is a sample that dates $9.4 \mathrm{ka}$ B.P. from Narssaq, southwestern Greenland, where driftwood appears to be exceedingly rare (Weidick, 1975). Otherwise the initial arrival of driftwood dates to about $8.5 \mathrm{ka}$ B.P. Only sparse wood arrived until $6.75 \mathrm{ka}$ B.P., when abundance increased and was sustained until 4 ka B.P. A distinct peak in driftwood in this region dates to the period from 5.25 to $5 \mathrm{ka} \mathrm{B.P.} \mathrm{The} \mathrm{preferential}$ accumulation of the Jones Sound wood on east-facing beaches, along with the occurrence of pumice of probable Icelandic origin on the $5 \mathrm{ka}$ B.P. beach, suggests delivery from Baffin Bay rather than from the northwest (Blake, 1972). Little wood arrived during the last $4 \mathrm{ka}$, except for the renewed abundance of the last 250 years.

Region not Accessible from Baffin Bay: Most of the Canadian Arctic Archipelago can receive driftwood only from the Arctic Ocean. We subdivide this large region into three in the following discussion, which proceeds downdrift, from north to south.

The Arctic Ocean shores of Ellesmere Island are of two fundamentally different types: those that are presently bound
TABLE 1. Larix to Picea ratios, expressed as numbers of identified samples, for four time intervals in various regions of the Canadian Arctic Archipelago and Svalbard.

\begin{tabular}{lcccc}
\hline \hline \multirow{2}{*}{ Region } & \multicolumn{4}{c}{ Time interval (ka B.P.) } \\
\cline { 2 - 5 } & $>6.75$ & $6.75-5$ & $5-3$ & $<3$ \\
\hline Baffin Bay & $2: 5$ & $4: 20$ & $1: 15$ & $1: 11$ \\
Arctic Ocean coast & $2: 6$ & $10: 5$ & $10: 5$ & $3: 11$ \\
Western Channels & $3: 4$ & $2: 1$ & $0: 4$ & $4: 13$ \\
Central Channels & $2: 8$ & $9: 7$ & $17: 16$ & $8: 33$ \\
Southwestern Channels & $0: 0$ & $0: 0$ & $0: 1$ & $1: 3$ \\
Svalbard & $29: 10$ & $13: 3$ & $15: 3$ & $12: 0$ \\
\hline \hline
\end{tabular}

TABLE 2. Probabilities, expressed as percentages, that a number of radiocarbon dates will fall into one histogram class as a result of chance alone ${ }^{1}$.

\begin{tabular}{cccccc}
\hline \hline $\begin{array}{l}\text { No. of } \\
\text { Dates }\end{array}$ & $\begin{array}{c}\text { Baffin } \\
\text { Bay }\end{array}$ & $\begin{array}{c}\text { Arctic } \\
\text { Ocean }\end{array}$ & $\begin{array}{c}\text { Western } \\
\text { Channels }\end{array}$ & $\begin{array}{c}\text { Central } \\
\text { Channels }\end{array}$ & Svalbard \\
\hline 0 & 14.3 & 11.4 & 33.3 & 4.9 & 0.8 \\
1 & 28.2 & 25.1 & 37.1 & 15.0 & 4.0 \\
2 & 27.4 & 27.3 & 20.2 & 22.7 & 9.7 \\
3 & 17.4 & 19.4 & 7.1 & 22.6 & 15.5 \\
4 & 6.9 & 8.6 & & 14.1 & 15.7 \\
5 & 3.1 & 4.3 & & 10.0 & 17.6 \\
6 & 0.9 & 1.5 & & 4.8 & 13.9 \\
7 & 0.2 & 0.4 & & 2.0 & 9.3 \\
8 & 0.1 & & & 0.7 & 5.5 \\
9 & & & & 0.2 & 2.8 \\
\hline \hline
\end{tabular}

${ }^{1}$ The number of dates (x) falling into any one class out of the total number of radiocarbon age determinations ( $\mathrm{n}$ ) is a random variable having the binomial probability distribution

$$
f(x)=(n ! /((n-x) ! x !)) p^{x}(1-p)^{n-x}
$$

where $\mathrm{p}$ is the constant probability of a date falling in any class (Freund, 1967).

by ice shelves (multiyear landfast sea ice) and those that are not. Driftwood occurs in the raised beaches landward of the ice shelves, having stranded there before they formed. Because this wood provides a means of limiting the time of formation of these ice shelves, many samples have been dated. The youngest wood landward of the ice shelves is 3-4 ka old (Fig. 4; Crary, 1960; Lyons and Meilke, 1973; Lemmen et al., 1988).

The aggregate distribution of driftwood dates from the Arctic Ocean coast of Ellesmere Island resembles that for the Baffin Bay region (cf. Figs. 3 and 4). However, this similarity is largely due to the effort applied to dating wood behind the ice shelves. When only samples from areas without ice shelves are considered, important differences appear between the records of the two regions. For example, the decline of wood abundance during the late Holocene, a prominent feature of the Baffin Bay record, is not apparent here (cf. Figs. 3 and 4). This part of the archipelago is nearest to wood sources, and the two oldest dated wood samples from the entire archipelago are from here, both from $8.9 \mathrm{ka}$ B.P. (Stewart and England, 1983; Bednarski, 1986; Lemmen, 1988). Driftwood arrived in only moderate abundance until 
$6.75 \mathrm{ka}$ B.P., when it increased coincidentally with its increase in Jones Sound. Prominent modes of driftwood arrival date from 6 to $5.75 \mathrm{ka} \mathrm{B.P.} \mathrm{and} \mathrm{from} 4.75$ to $4.5 \mathrm{ka}$ B.P. The strong mode in Jones Sound between 5.25 and 5 ka B.P. correlates with a minimum in the northern Ellesmere record (cf. Figs. 3 and 4).

The driftwood record for the large Western Channels region (Fig. 2) is represented by only 39 samples (Fig. 5). This presumably reflects more the scarcity of wood on the emerged terrain than a lack of effort at collecting and dating. Most wood in the region appears to fall into two broad age groups: from 9 to $4.75 \mathrm{ka}$ B.P. and from 3.5 to 0 ka B.P.; wood of the younger age group appears to be more abundant. Note that the probabilities of the number of dates per class in this distribution being due to chance are relatively high (Table 2). Furthermore, in a test of randomness based on the number of runs above and below the median age of the samples, the null hypothesis that this distribution is random cannot be rejected at the 0.05 level of significance. In this case the runs (14) were generated by sorting the data by laboratory number. The number of runs expected in a random sample of this size has a normal distribution with a mean and standard deviation of 20 and 6.

More than 100 driftwood samples have been dated from the Central Channels (Figs. 2 and 6). Initial driftwood incursion is represented by three samples that date to $8.6 \mathrm{ka}$ B.P. Driftwood arrived sparsely between 8.6 and 6 ka B.P. when it suddenly, but briefly, increased to one of two middle Holocene maxima, between 6 and 5.75 ka B.P. This modal abundance correlates exactly with the mode for the northern coast of Ellesmere Island (cf. Figs. 4 and 6). Thus this brief event of abundant wood arrival is widely recorded. Similarly, both records display driftwood minima between 5.25 and $5 \mathrm{ka}$ B.P. that, in turn, correlate with the modal abundance in the Baffin Bay region (cf. Figs. 4 and 6 with 3). The mode between 4.75 and $4.25 \mathrm{ka}$ B.P. in the central Arctic appears to be represented in both the northern Ellesmere and the Baffin Bay records. The strong central Arctic mode between 3.75 and $3.5 \mathrm{ka} \mathrm{B.P.} \mathrm{corresponds} \mathrm{with} \mathrm{the} \mathrm{sharp} \mathrm{decline} \mathrm{in} \mathrm{wood}$ abundance in the Baffin Bay region.

Late Holocene driftwood abundance in the Central Channels region is seriously underrepresented by Figure 6. As pointed out by Dyke and Morris (1990:7), "virtually all samples that were collected from elevations that would indicate ages greater than about 3000 years were dated...Samples from lower elevations were selectively dated (about 1 out of 3 collected) and not all wood...1000 years old and less was sampled because of the considerable abundance." Hence the histogram underrepresents the relative abundance of wood younger than 3000 years by a factor of two or more. Unfortunately, no systematic surveys of wood abundance are available on which to base a quantitative correction for these biases in collecting and dating. There may be significant variability in wood incursion in the Central Channels during the last $3 \mathrm{ka}$, but this needs to be assessed further by more extensive dating of low-elevation samples.
The contrast between the relative abundance of middle Holocene driftwood in the Central Channels (Fig. 6) and the near absence of it in the Western Channels (Fig. 5) is odd, because the latter region generally lies closer to the wood source. That is, most of the wood of middle Holocene age arriving in the Central Channels must have passed through the Western Channels region. If so, it would seem that the stranding potential for wood during the middle Holocene was quite different in the two regions. Possibly extensive landfast ice persisted through the summers in much of the Western Channels region and prevented stranding of wood, but more extensive sampling of the Western Channels region is required before this can be stated confidently.

Taken as a single region, those parts of the archipelago not accessible to driftwood from Baffin Bay (Fig. 7) display the following broad features:

1) initial incursion of wood just after $9 \mathrm{ka}$; sparse wood incursion until $6 \mathrm{ka}$;

2) a sharp peak of wood incursion from 6 to $5.75 \mathrm{ka}$ B.P., succeeded by a minimum between 5.25 and 5 ka B.P.;

3) moderately abundant wood incursion for the rest of the middle Holocene; and

4) maximum postglacial incursion during the last $2.5-3$ ka.

\section{Summary of Major Correlations}

Given the hypothesis of shifting of the TPD, we should expect positive correlations between the driftwood records for the two major regions of Arctic Canada during times of a split TPD and negative correlations during other times (Fig. 8). The major positive correlations are:

1) initial wood incursions generally from 9 to $8.5 \mathrm{ka}$ B.P. followed by sparse incursions; and

2) a general increase in middle Holocene wood incursion. The major negative correlations are:

1) the strong modal abundance in the main archipelago from 6 to $5.75 \mathrm{ka}$ B.P. has no counterpart in the Baffin Bay region;

2) the strong modal abundance in the Baffin Bay region from 5.25 to $5 \mathrm{ka}$ B.P. correlates with a minimum in the rest of the archipelago; and

3 ) the strong late Holocene (Neoglacial) decline of driftwood in the Baffin Bay region correlates with a strong increase of driftwood in most of the rest of the archipelago.

\section{Svalbard}

Lateral shifts of the TPD on the scale postulated here would not necessarily affect delivery of driftwood to Svalbard as greatly as delivery to the Canadian Arctic Archipelago. Although an eastward displacement of the distal TPD could greatly diminish or shut off wood supply to most of the Canadian Arctic, a westward displacement would not have the same effect on Svalbard because it would remain accessible to wood from western Eurasia via the Barents Sea. This 


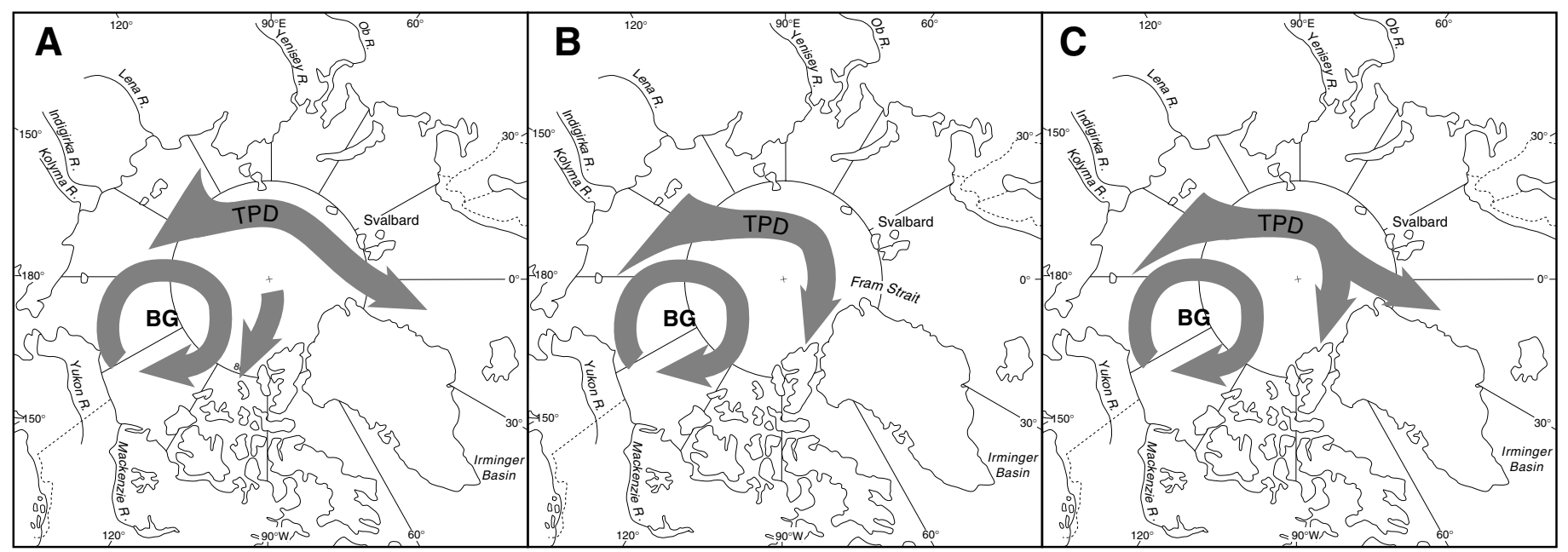

FIG. 8. A model for interpreting the driftwood chronologies of Arctic Canada. Configurations A and B produce negatively correlated wood abundances in the two major regions. Configuration $\mathrm{C}$ produces positively correlated abundances.

is illustrated in the study by Eggertsson (1994a). He found that when wood supply via the Barents Sea (West Spitsbergen Current) declines, it is replaced by wood delivered by the TPD. Each source supplies a distinct mix of tree genera, with the TPD contributing mostly larch. Given the potentially different sources, we should expect to find meaningful correlations, positive or negative, between the records for Svalbard and Arctic Canada only if (a) the flux of wood to Svalbard was always dominated by the TPD or (b) the contribution from the TPD could be extracted from the total and separately analyzed.

A review of the journal Radiocarbon and reports on the Quaternary geology of Svalbard yielded 194 radiocarbon dates on driftwood (Fig. 9; Blake, 1961; Hoppe et al., 1969; Salvigsen, 1978, 1981; Häggblom, 1982; Salvigsen and Österholm, 1982; Forman et al., 1987; Landvik et al., 1987; Forman 1990a, b; Österholm, 1990; Salvigsen and Mangerud, 1991; Gulliksen et al., 1992; Bondevik et al., 1995). Supply of wood to Svalbard apparently was irregular during Holocene time (Häggblom, 1982; Fig. 9), but there were only brief intervals, if any, when wood did not arrive at all.

It is difficult to interpret the frequency distribution of radiocarbon dates in Figure 9 without knowing the biases involved in sample collection and in selection for dating (cf. discussions of central Arctic and northern Ellesmere Island, above) and without being able to separate the TPD contribution from the rest. Two comparisons with the record for Arctic Canada can be made. The first may be the only significant one:

1) Wood was arriving in Svalbard for more than a millennium before its first dated arrival in Arctic Canada. Furthermore, its first widespread arrival in Arctic Canada (8.6 ka B.P.) coincides with an apparent decrease in arrival in Svalbard.

2) The strong maximum in driftwood incursion to that part of the Canadian Arctic Archipelago not accessible from Baffin Bay between 6 and 5.75 ka B.P. corresponds to a time of apparently diminishing driftwood incursion to Svalbard (cf. Figs. 7 and 9).
Among identified samples that we have noted from Svalbard, the Larix to Picea ratio for the whole Holocene is 3.8. Although 10 of 18 identified spruce are of early Holocene age (more than $6.75 \mathrm{ka} \mathrm{B.P.),} \mathrm{the} \mathrm{ratio} \mathrm{even} \mathrm{then} \mathrm{is} 2.9$ (Table 1). These ratios exceed those for the larch-rich driftwood zone of Arctic Canada, and they seem to increase through the Holocene. The high Svalbard ratios suggest (a) that Eurasian wood never had comparable access to the Canadian Arctic; and (b) that western North American wood has never dominated the flux to Svalbard but may have been a more significant component in the early Holocene than later. Alternatively, the spruce on Svalbard may have come entirely from western Eurasia.

\section{ESTABLISHMENT OF THE PRESENT INTERGLACIAL OCEAN CIRCULATION IN THE CANADIAN ARCTIC ARCHIPELAGO}

The initial arrival of driftwood to widespread stranding sites in the Canadian Arctic Archipelago dates close to 8.5-8.6 ka B.P.; older samples are rare and from sites nearest to wood sources-Narssaq, Greenland (9.4 ka B.P.) and northernmost Ellesmere Island (8.9 ka B.P.). Yet before $8.5 \mathrm{ka} \mathrm{B.P.,} \mathrm{the} \mathrm{Arctic} \mathrm{Ocean} \mathrm{clearly} \mathrm{received} \mathrm{and}$ transported driftwood, as attested by the Svalbard wood chronology (Fig. 9) and by the presence of spruce near the Mackenzie Delta as early as 11.6 ka B.P. (Ritchie and Hare, 1971; Hopkins et al., 1981). Spruce advanced generally into the Yukon watershed of eastern Alaska between 9.5 and 9 ka B.P. (Anderson et al., 1994) and at about 10 ka B.P. into the Yukon Territory (Clague and MacDonald, 1989). The boreal forests of both continents have been so large since about 10 ka B.P. (Khotinskiy, 1984; Ritchie, 1989) that the supply of wood to the Arctic Ocean has probably been nearly constant, especially on a 250 -year average. Furthermore, bowhead whales (Balaena mysticetus) ranged widely and abundantly in the Canadian 


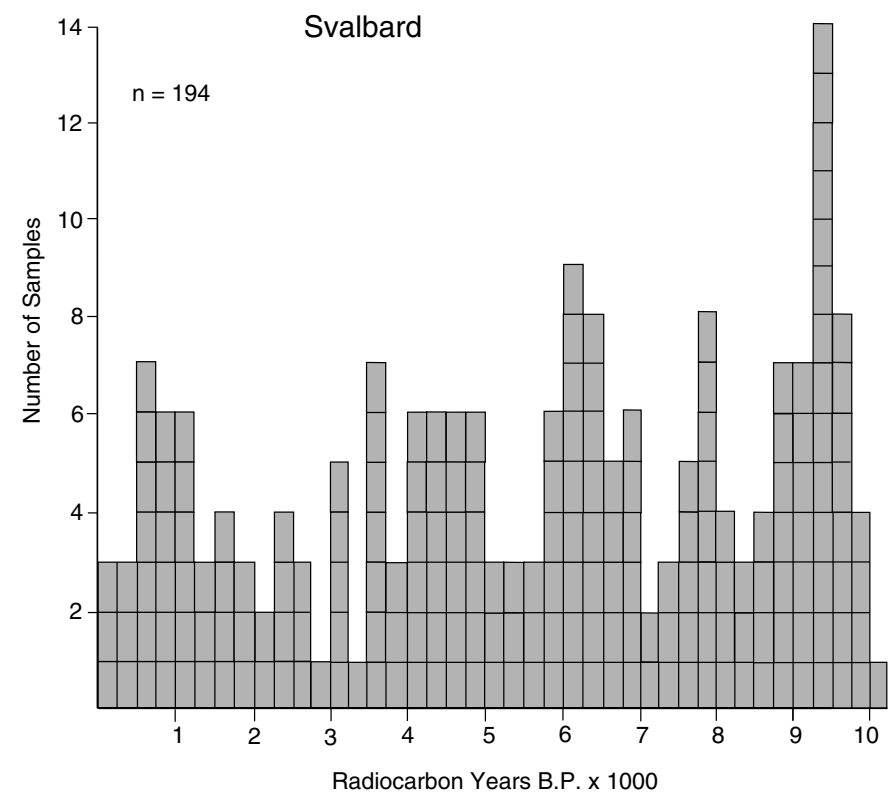

FIG. 9. Frequency distribution of radiocarbon dates on driftwood from Svalbard.

Arctic Archipelago between 10.5 and 8.5 ka B.P. (Dyke and Morris, 1990; Dyke et al., 1996b). Therefore, driftwood must have been excluded from the area before $8.6 \mathrm{ka}$ B.P. by something other than local sea-ice conditions or glacier cover.

The initial widespread incursion of driftwood coincided with a sudden contraction of the summer range of the bowhead whale. This coincidence can be explained by the switch from a glacial ocean circulation pattern, driven by meltwater outflow from the archipelago, to the present southeastward filtration of Arctic Ocean Surface Water through the archipelago (Fig. 1). On establishment, the through flow brought sea ice from the Arctic Ocean that both carried driftwood and evidently restricted the bowhead whale range (Dyke et al., 1996b).

A number of correlative changes at about $8.5 \mathrm{ka}$ B.P. may be interrelated. Aksu (1983) estimated the onset of Arctic Ocean Surface Water flux through to Baffin Bay at about $8 \mathrm{ka}$ B.P. based on the start of a foraminiferal dissolution event in Baffin Bay. Rahman and De Vernal (1994) concluded from the nannofossil record of two deep-sea cores that the Labrador Current became stronger at 8.4 ka B.P., while the West Greenland Current became warmer. The latter event was at least partly responsible for the expansion of boreal-subarctic molluscs into Baffin Bay at about 8.5 ka B.P. (Funder and Weidick, 1991; Dyke et al., 1996a). If the start of outflow of Arctic Ocean Surface Water through the Canadian Arctic Archipelago dates to the period between 8.6 and $8.5 \mathrm{ka} \mathrm{B.P.,}$ as we infer from the driftwood and bowhead whale records, the Arctic Ocean outflow through Fram Strait should have slackened at the same time, allowing warming of currents downdrift and a relatively greater contribution of Irminger Current water to the West Greenland Current. The present outflow via the Canadian route is $30 \%$ of the total, but the early Holocene flow was probably larger because the interisland channels were much wider and as much as $140 \mathrm{~m}$ deeper.

\section{SHIFTS OF THE TRANSPOLAR DRIFT}

In our hypothesis, changes in the supply of driftwood to the Canadian Arctic Archipelago after 8.5 ka B.P. were caused by shifts in the trajectory of the TPD. The data suggest the following chronology:

8.5-6.75 ka B.P.: the TPD was split more or less evenly at northeast Greenland and delivered wood to both the archipelago and northern Baffin Bay; most wood arriving in both regions was spruce, presumably of North American origin; the West Greenland Current was fully established by $8.5 \mathrm{ka}$ B.P. (Funder and Weidick, 1991) but did not penetrate strongly to the head of Baffin Bay before that.

6.75-6 ka B.P.: an increase in driftwood incursion (mostly spruce) to northern Baffin Bay and sustained low levels of incursion to the rest of the archipelago suggest that more of the TPD exited via the East Greenland Current than before; the fact that mostly North American wood was exiting the western side of Fram Strait agrees with an eastward shift of the TPD path; mostly Eurasian wood (larch) arriving at Svalbard at this time, and subsequently, indicates that the TPD was never entirely displaced east of there.

6-5.75 ka B.P.: a sudden spike of driftwood arrivals throughout most of the Canadian Arctic Archipelago suggests a westward shift of much, or all, of the distal end of the TPD for an interval of 250 years or less; incursion of Russian wood (larch) indicates substantial shifting (more than just the Polar Branch) or more internal eddying in the TPD.

5.75-5.25 ka B.P.: the TPD was split nearly evenly at northeast Greenland.

5.25-5 ka B.P.: a sudden spike of driftwood arrivals in northern Baffin Bay and its coincidence with a near cessation in driftwood arrivals in the rest of the archipelago suggest an eastward shifting of much or all of the distal TPD.

5-4 ka B.P.: the TPD was split more or less evenly.

4-0.25 ka B.P.: a sudden spike of driftwood arrivals in the archipelago suggests a westward shift of the distal TPD at about 4 ka B.P. Little wood arrived in northern Baffin Bay after 4 ka B.P., while wood was delivered in maximum postglacial abundance to the archipelago. The late Holocene (Neoglacial) was the longest period of predominantly westward configuration of the distal TPD. However, the strong dominance of North American wood arriving in the Canadian Arctic Archipelago and the dearth of wood reaching Baffin Bay suggest that Russian and North American wood dispersion was greatly differentiated, with Russian wood deflected to Svalbard or farther east.

0.25-0 ka B.P.: increase of wood arrivals in northern Baffin Bay and continued arrival of wood in the archipelago 
suggests either (a) a split TPD, or (b) the introduction of mechanized, large-scale logging operations in Eurasia.

\section{DISCUSSION}

The contrasting regional chronologies of postglacial driftwood incursion in Arctic Canada can be fully explained by the hypothesis that the TPD shifted by about its own width irregularly during postglacial time. This hypothesis is generally supported, or at least not contradicted, by the driftwood data from Svalbard. The hypothesis is based not on the driftwood chronologies themselves, but on the fact that the TPD carries almost all wood of both North American and Russian origin across the Arctic Ocean. The earlier climatological hypothesis, that periods of abundant wood incursion signify more open-water conditions off the stranding sites (Blake, 1972), cannot explain either the positive or, more importantly, the negative correlations between the different regional chronologies. Nor can it account for the changing mix of wood types through time in any region. Furthermore, the open-water hypothesis conflicts with independent indications of sea-ice conditions based on remains of the bowhead whale, an animal behaviorally adapted to live in the loose edge of the sea ice. The opposing climatological hypothesis, that periods of abundant wood incursion signify brief summers with less sea-ice clearance (Häggblom, 1982), similarly does not explain the correlations and changing wood types, nor does it explain why wood advected to a region during the nonsummer months should fail to strand during seasonal breakup.

Other speculative causes of changes in wood incursion rates, such as fluctuations of regional treelines or river bank erosion rates, seem similarly incapable of explaining any of the salient features of the available driftwood records. Bank erosion, on time scales used in this paper, is probably a rather constant process that would not change drastically without more fundamental changes in the drainage systems. Similarly, Holocene forest cover changes in the source areas are not likely to have been abrupt enough or large enough to have generated the strong, punctual signals in distal regions described above. For example, a tree line fluctuation of $100 \mathrm{~km}$ in the Mackenzie drainage would change the cumulative length of river courses traversing the boreal forest by only about $1 \%$. In addition, although there have been changes in boreal forest limits on both continents during the Holocene (Nichols, 1976; Moser and MacDonald, 1990; MacDonald and Velichko, 1994), it is entirely unclear how these changes can be invoked to explain cogently the details of the driftwood records.

The feasibility of our hypothesis would be bolstered if mechanisms for shifting the TPD could be identified. While it is beyond the scope and intent of this paper to do this rigorously, it may be useful to speculate about possibilities. We briefly consider three.

Over short intervals, equal to Arctic Ocean transit times, the export of ice from the Arctic Ocean by the TPD must balance ice production. Export rates are known to be variable, but ice production rates have more than one control. Mysak and Power (1991, 1992), among others, have described modern sea-ice and salinity anomalies that migrated from the Greenland Sea to the Labrador Sea and that arose from increased outflow of sea ice through Fram Strait via the TPD. These anomalies, in turn, have been traced back to increases in Mackenzie River discharge a few years earlier and to the resulting increases in sea-ice production in the Beaufort Sea. Thus, changes in the outflow of the TPD may be caused by the ordinary mechanism of regional precipitation changes. Possibly, on time scales of centuries to millennia, regional precipitation changes could affect the position, as well as the flux, of the TPD. For example, increased river discharges into the Beaufort Gyre (Fig. 1) might shift the TPD to the left, whereas increased discharges into the gyres on the Eurasian side of the TPD might shift it to the right to accommodate the regionally increased water and ice fluxes. Simultaneous discharge increases or decreases on both sides would presumably result in changes in the speed of the TPD.

Another, likely more important, control on Arctic Ocean sea-ice production that might have changed during the Holocene is the size and position of large polynyas off Siberia (Reimnitz et al., 1994). The Laptev Sea polynya is considered the single major ice factory for the Arctic Ocean today, followed by polynyas in the East Siberian and Kara Seas (Fig. 1). These latent-heat polynyas, maintained by offshore winds, result in upwelling and high production rates for winter sea ice that is continuously advected into the TPD. The polynyas contact landfast ice along their inner margins, which tend to lie along the 20-30 m isobath. Changes in sea level alone during the Holocene would have changed the locations and configurations of these polynyas and hence ice production rates.

Yet another mechanism that could affect both the path and turbulence of the TPD is suggested by the seasonal reversals of the Beaufort Gyre (McLaren et al., 1987; Serreze and Barry, 1988). Longer-term changes in the variability of atmospheric and oceanic circulation could result from changes in the strength, persistence, and positions of the Mackenzie and Siberian highs. In that the Beaufort Gyre and TPD are wind-driven, changes in atmospheric circulation are perhaps the most likely mechanism for shifting the path of the TPD.

The TPD is one of the world's major ocean currents. Hence, our hypothesis that its distal end can take eastern, split, or western discharge routes under "normal" interglacial conditions has several important implications. Like other major currents, its characteristics - temperature, salinity, and sea-ice load-partly dictate the characteristics of the currents into which it extends: the East Greenland, West Greenland, Baffin, and Labrador Currents.

For example, when (or if) the TPD exits mostly or entirely through the Canadian Arctic Archipelago, it directly joins the Baffin, and later Labrador, currents without the benefit of the warming that it otherwise would receive from mixing with water of the North Atlantic Drift in the Irminger Basin. Therefore, downstream effects of changes in the TPD are likely significant for the fisheries 
resources and sea-ice conditions of eastern Canada, Iceland, and Greenland. Variations in the strength and temperature of the West Greenland Current during this century resulted in a shifting of marine faunal resources of great economic and biogeographic significance; this included the establishment of commercial Atlantic cod and Atlantic salmon fisheries in West Greenland (Dunbar, 1976; Harington, 1980). During the same interval, the TPD had a lesser effect, and the warm West Spitsbergen Current a greater effect, on the marine and terrestrial climate of Svalbard (Eggertsson, 1994a).

Furthermore, varying the amount and spatial pattern of sea-ice export from the Arctic Ocean to the North Atlantic has strong feedbacks on both ocean and atmospheric circulation: years of heavy sea-ice export result in fresher surface waters in the ablation areas, reduced thermohaline circulation because of density stratification, less heating of the atmosphere because of reduced upwelling, and consequently less cyclogenesis (Mysak and Power, 1991, 1992).

Finally, sea ice has been shown to be an important sediment entrainment and transport agent. The sediment is associated with the drifting wood and now with pollutants (Reimnitz et al., 1994). The young age of some of the stranded driftwood, extending into the time of industrialization, indicates that anthropogenic pollutants, like radionuclides and PCBs of Russian origin, are getting into the Canadian Arctic Archipelago and Labrador Sea.

Because the ecology and economy of the North Atlantic, especially the Canadian sector, are intricately linked to processes occurring in the Arctic, it is important to probe further the validity of the proposed hypothesis and the possible causes of the shifts in TPD, so that future events and their consequences can be more thoroughly considered, if not predicted. During the Holocene, the various inferred discharge routes of the TPD were stable for intervals ranging from millennia to centuries, or perhaps only decades for some shifts. Possibly these represent responses to different mechanisms or different thresholds of the same mechanism. The general correlation of the last major, and the most stable, inferred change in TPD routing with the Neoglacial period suggests an underlying climatic forcing mechanism. Increased radiocarbon and wood taxonomic databases are needed from Arctic Canada, Greenland, and Svalbard, in order to properly evaluate, elaborate, and improve or replace our hypothesis.

\section{ACKNOWLEDGEMENTS}

We are indebted to the small groups of researchers who, over the years, have collected driftwood samples for radiocarbon dating. These people are identified only partly in the list of references. In Arctic Canada, they include W. Blake, Jr., D.A. Hodgson, D.M. Barnett, and R.B. Taylor, all now or formerly of the Geological Survey of Canada (GSC) and J. Bednarski (GSC), T. Stewart, D.S. Lemmen (GSC), T.F. Morris, D.E.C. Green, and J. Hooper, all former graduate students of the University of Alberta.
Dozens of wood samples have been identified from thin sections by R.J. Mott as Director of GSC's Paleoecology Laboratory; Bob specifically identified John England's dated samples from Ellesmere Island and reexamined 16 samples for this paper while it was in review. He also trained others who have continued this work (L.D. Farley-Gill and H. Jetté). Most of our radiocarbon dates on driftwood were produced by laboratories at GSC, Saskatchewan Research Council, and the University of Toronto (IsoTrace). R.N. McNeely, who directs the GSC laboratory, has greatly expedited this and related studies through his constant maintenance and updating of the Canadian Radiocarbon Database.

Virtually all fieldwork in Arctic Canada that this paper draws on was supported by the Polar Continental Shelf Project, GSC. England's fieldwork and radiocarbon dating, and that of his students, were supported by Natural Sciences and Engineering Research Council of Canada Grant A6680. Reimnitz is grateful for past arctic logistical support provided by the United States Geological Survey and for observations on driftwood by expedition colleagues and by sailors of the United States Coast Guard. Our thanks to J.T. Andrews (U. of Colorado), W. Blake, Jr. (GSC Ottawa), C.R. Harington (Canadian Museum of Nature), D.A. Hodgson (GSC Ottawa), D. Lubinski (U. of Colorado), J.B. Macpherson (Memorial U.), P. Mudie (GSC Dartmouth), and L.A. Mysak (McGill U.) for helpful discussion and reviews during preparation of the manuscript. Formal reviews by O. Salvigsen (Norsk Polarinstitutt), S.L. Forman (Ohio State U.), and an anonymous reviewer are appreciated.

\section{REFERENCES}

AKSU, A.E. 1983. Holocene and Pleistocene dissolution cycles in deep-sea cores of Baffin Bay and Davis Strait: Paleoceanographic implications. Marine Geology 53:331-348.

ANDERSON, P.M., LOZHKIN, A.V., EISNER, W.R., KOZHEVNIKOVA, M.V., HOPKINS, D.M., BRUBAKER, L.B., and COLINVAUX, P.A. 1994. Two late Quaternary pollen records from south-central Alaska. Géographie physique et Quaternaire 48:131-144.

ARCTIC SYSTEM SCIENCE. 1990. Ocean-atmosphere-ice interactions. Washington: Joint Oceanographic Institute Report. $132 \mathrm{p}$.

ARNOLD, C.D. 1994. The importance of wood in the Early Thule culture of the western Canadian Arctic. In: Morrison, D., and Pilon, J.-L., eds. Threads of Arctic prehistory: Papers in honour of William E. Taylor, Jr. Canadian Museum of Civilization, Mercury Series, Archaeological Survey of Canada Paper 149. 269-279.

BARRY, R.G. 1989. The present climate of the Arctic Ocean and possible past and future states. In: Herman, Y., ed. The Arctic seas-Climatology, oceanography, geology, and biology. New York: Van Nostrand Reinhold Company. 1-46.

BEDNARSKI, J. 1986. Late Quaternary glacial and sea-level events, Clements Markham Inlet, northern Ellesmere Island, Arctic Canada. Canadian Journal of Earth Sciences 23:1343-1355.

BLAKE, W., Jr. 1961. Radiocarbon dating of raised beaches in Nordaustlandet, Spitsbergen. In: Raasch, G.O., ed. Geology of the Arctic. Toronto: University of Toronto Press. 133-145. 
1972. Climatic implications of radiocarbon-dated driftwood in the Queen Elizabeth Islands, Arctic Canada. In: Vasari, Y., Hyvarinen, H., and Hicks, S., eds. Climatic changes in Arctic areas during the last 10,000 years. Acta Universitatis Ouluensis, Series A, Geologica No. 1:77-104.

- 1975. Radiocarbon age determinations and postglacial emergence at Cape Storm, southern Ellesmere Island, Arctic Canada. Geografiska Annaler 57A:1-71.

BONDEVIK, S., MANGERUD, J., RONNERT, L., and SALVIGSEN, O. 1995. Postglacial sea-level history of Edgeøya and Barentsøya, eastern Svalbard. Polar Research 14:153-180.

CLAGUE, J.J., and MacDONALD, G.M. 1989. Paleoecology and paleoclimatology, Canadian Cordillera. In: Fulton, R.J., ed. Quaternary geology of Canada and Greenland. Geological Survey of Canada, Geology of Canada, No. 1. 70-74.

CRARY, A.P. 1960. Arctic ice island and ice shelf studies: Part II. Arctic 13:32-50.

DUNBAR, M.J. 1976. Climatic change and northern development. Arctic 29:183-193.

DYKE, A.S., and MORRIS, T.F. 1990. Postglacial history of the bowhead whale and of driftwood penetration; implications for paleoclimate, central Canadian Arctic. Geological Survey of Canada, Paper 89-24. 17 p.

DYKE, A.S., DALE, J.E., and McNEELY, R.N. 1996a. Marine molluscs as indicators of environmental change in glaciated North America and Greenland during the last 18000 years. Géographie physique et Quaternaire 50:125-184.

DYKE, A.S., HOOPER, J., and SAVELLE, J.M. 1996b. A history of sea ice in the Canadian Arctic Archipelago based on postglacial remains of the bowhead whale (Balaena mysticetus). Arctic 49:235-255.

EGGERTSSON, O. 1993. Origin of the driftwood on the coasts of Iceland: A dendrochronological study. Jökul 43:15-32.

- 1994a. Driftwood as an indicator of relative changes in the influx of Arctic and Atlantic water into the coastal areas of Svalbard. Polar Research 13:209-218.

- 1994b. Mackenzie River driftwood-A dendrochronological study. Arctic 47:128-136.

EGGERTSSON, O., and LAEYENDECKER, D. 1995. A dendrochronological study of the origin of driftwood in Frobisher Bay, Baffin Island, N.W.T., Canada. Arctic and Alpine Research 27:180-186.

EUROLA, S. 1971. The driftwoods of the Arctic Ocean. Report of the Kevo Subarctic Research Station 7:74-80.

FORMAN, S.L. 1990a. Svalbard radiocarbon dates 1. Institute of Arctic and Alpine Research, University of Colorado, Occasional Paper 47. 48 p.

- 1990b. Post-glacial relative sea-level history of northwestern Spitsbergen, Svalbard. Geological Society of America Bulletin 102:1580-1590.

FORMAN, S.L., MANN, D.H., and MILLER, G.H. 1987. Late Weichselian and Holocene sea-level history of Bröggerhalvöya, Spitsbergen. Quaternary Research 27:41-50.

FREUND, J.E. 1967. Modern elementary statistics. Englewood Cliffs, New Jersey: Prentice-Hall, Inc. 432 p.
FUNDER, S., and WEIDICK, A. 1991. Holocene boreal molluscs in Greenland-Palaeoceanographic implications. Palaeogeography, Palaeoclimatology, Palaeoecology 85:123-135.

GIDDINGS, J.L., Jr. 1952. Driftwood and the problem of arctic sea currents. Philadelphia: American Philosophical Society Proceedings 96:129-142.

GULLIKSEN, S., HEINEMEIER, J., NIELSEN, S.H., NYDAL, R., RUD, N., SKOG, G., THOMSEN, M.S., and LANDVIK, J.Y. 1992. ${ }^{14} \mathrm{C}$-dating of samples collected during the 1991 PONAM expedition to eastern Svalbard. LUNDQUA Report 35:191- 198 .

HÄGGBLOM, A. 1982. Driftwood in Svalbard as an indicator of sea ice conditions. Geografiska Annaler 64A:81-94.

HARINGTON, C.R. 1980. The impact of climatic change on people in Canada and the National Museum of Natural Sciences climatic change project. Syllogeus 26:5-15.

HOPKINS, D.M., SMITH, P.A., and MATTHEWS, J.V., Jr. 1981. Dated wood from Alaska and the Yukon: Implications for forest refugia in Beringia. Quaternary Research 15:217-249.

HOPPE, G., SCHYTT, V., HÄGGBLOM, A., and ÖSTERHOLM, H. 1969. Studies of the glacial history of Hopen (Hopen Island), Svalbard. Geografiska Annaler 51A:186-192.

HUSTICH, I. 1966. On the forest-tundra and the northern tree lines. Annales Universitatis Turkuensis A II (36), Reports from the Kevo Subarctic Research Station 3:7-47.

KHOTINSKIY, N.A. 1984. Holocene vegetation history. In: Velichko, A.A., ed. Late Quaternary environments of the Soviet Union. (Wright, H.E., and Barnowsky, C.W., editors of the English language edition.) Minneapolis: University of Minnesota Press. 179-200.

KINDLE, E.M. 1921. Mackenzie River driftwood. Geographical Review 11:50-53.

KOERNER, R.M. 1989. Queen Elizabeth Islands glaciers. In: Fulton, R.J., ed. Quaternary geology of Canada and Greenland. Geological Survey of Canada, Geology of Canada, No. 1. 464-473.

LANDVIK, J.Y., MANGERUD, J., and SALVIGSEN, O. 1987. The Late Weichselian and Holocene shoreline displacement on the west-central coast of Svalbard. Polar Research 5:29-44.

LEMMEN, D.S. 1988. The glacial history of Marvin Peninsula, northern Ellesmere Island, and Ward Hunt Island, High Arctic Canada. Ph.D. thesis, University of Alberta, Edmonton. 174 p.

LEMMEN, D.S., EVANS, D.J.A., and ENGLAND, J. 1988. Ice shelves of northern Ellesmere Island, NWT. The Canadian Geographer 32:363-367.

LYONS, J.B., and MEILKE, J.E. 1973. Holocene history of a portion of northernmost Ellesmere Island. Arctic 26:314-323.

MacDONALD, G.M., and VELICHKO, A.A. 1994. Macrofossil evidence of early to mid-Holocene northward extension of treeline in western Siberia. Geological Association of Canada, Mineralogical Association of Canada, Annual Meeting. Program with Abstracts 19:A69.

McLAREN, A.S., SERREZE, M.C., and BARRY, R.G., 1987. Seasonal variations of sea ice motion in the Canada Basin and their implications. Geophysical Research Letters 14:1123-1126.

McNEELY, R., and JORGENSEN, P.K. 1993. Geological Survey of Canada Radiocarbon Dates 31. Geological Survey of Canada, Paper 91-7. 85 p. 
MOSER, K.A., and MacDONALD, G.M. 1990. Holocene vegetation change at treeline north of Yellowknife, Northwest Territories. Quaternary Research 34:227-239.

MYSAK, L.A., and POWER, S.B. 1991. Greenland sea-ice and salinity anomalies and interdecadal climate variability. Climatological Bulletin 25:81-91.

MYSAK, L.A., and POWER, S.B. 1992. Sea-ice anomalies in the western Arctic and Greenland-Iceland Sea and their relation to an interdecadal climate cycle. Climatological Bulletin 26: $147-176$.

NICHOLS, H. 1976. Historical aspects of northern Canadian treeline. Arctic 29:38-47.

OSTENSO, N.A. 1966. Arctic Ocean. In: Fairbridge, R.W., ed. The encyclopedia of oceanography. New York: Reinhold Publishing Corporation. 49-55.

ÖSTERHOLM, H. 1990. The Late Weichselian glaciation and Holocene shore displacement on Prins Oscars Land, Nordaustlandet, Svalbard. Geografiska Annaler 72A:301 - 317.

PANSHIN, A.J., and DE ZEEUW, C. 1980. Textbook of wood technology. 4th ed. New York: McGraw-Hill Book Company. $722 \mathrm{p}$.

PFIRMAN, S., GASCARD, J.-C., WOLLENBURG, I., MUDIE, P., and ABELMANN, A. 1989. Particle-laden Eurasian Arctic sea ice: Observations from July and August 1987. Polar Research 7:59-66.

RAHMAN, A., and DE VERNAL, A. 1994. Surface oceanographic changes in the eastern Labrador Sea: Nannofossil record of the last 31,000 years. Marine Geology 121:247-263.

REIMNITZ, E., and MAURER, D.K. 1979. Effects of storm surges on the Beaufort Sea coast, northern Alaska. Arctic 32:329-344.

REIMNITZ, E., DETHLEFF, D., and NÜRNBERG, D. 1994. Contrasts in arctic shelf sea-ice regimes and some implications: Beaufort Sea versus Laptev Sea. Marine Geology 119:215225.

RIGOR, I. 1992. Arctic Ocean Buoy Program. ARCOS Newsletter $44: 1-3$.
RITCHIE, J.C. 1984. Past and present vegetation of the Far Northwest of Canada. Toronto: University of Toronto Press. $251 \mathrm{p}$.

1989. History of the boreal forest in Canada. In: Fulton, R.J., ed. Quaternary geology of Canada and Greenland. Geological Survey of Canada, Geology of Canada, No. 1. 508512.

RITCHIE, J.C., and HARE, F.K. 1971. Late Quaternary vegetation and climate near the Arctic treeline of northwestern North America. Quaternary Research 1:331-342.

SALVIGSEN, O. 1978. Holocene emergence and finds of pumice, whalebones, and driftwood at Svartknausflya, Nordaustlandet. Norsk Polarinstitutt Årbok 1977. 217-228.

. 1981. Radiocarbon dated raised beaches in Kong Karls Land, Svalbard, and their consequences for the glacial history of the Barents Sea area. Geografiska Annaler 63A:283-291.

SALVIGSEN, O., and MANGERUD, J. 1991. Holocene shoreline displacement at Agardbukta, eastern Spitsbergen, Svalbard. Polar Research 9:1-7.

SALVIGSEN, O., and ÖSTERHOLM, H. 1982. Radiocarbon dated raised beaches and glacial history of the northern coast of Spitsbergen, Svalbard. Polar Research 1:97-115.

SERREZE, M.C., and BARRY, R.G. 1988. Synoptic activity in the Arctic Basin, 1979-1985. Journal of Climate 1:1276-1295.

STEWART, T.G., and ENGLAND, J. 1983. Holocene sea-ice variations and paleoenvironmental change, northernmost Ellesmere Island, N.W.T., Canada. Arctic and Alpine Research 15:1- 17 .

WEIDICK, A. 1975. $\mathrm{C}^{14}$ dating of Survey material performed in 1974. Grønlands Geologiske Undersøgelse Rapport 85:127129.

WILLIAMS, L.D., and BRADLEY, R.S. 1985. Paleoclimatology of the Baffin Bay region. In: Andrews, J.T., ed. Quaternary environments: Eastern Canadian Arctic, Baffin Bay, and West Greenland. Boston: Allen and Unwin. 741-772.

ZUKOV, V.F. 1940. Plavnik. Sovietskaya Arktika 3:88-90. (Quoted in Eurola, 1971) 